Гиря В. М., кандидат сільськогосподарських наук Інститут свинарства і АПВ НААН

\title{
ДОЦІЛЬНІСТЬ ВИКОРИСТАННЯ ТЕОРІЇ ПРЕПОТЕНТНОСТІ У ТВАРИННИЦТВІ
}

\section{Рецензент - кандидат сільськогосподарських наук В. М. Нагаєвич}

\begin{abstract}
Висвітлюються окремі аспекти теорії препотентності тварин. Дається аналіз різних поглядів науковиів минулого й сучасності стосовно ї̈ значимості в процесі очінки продуктивності плідників у здатності передачі потомству своїх найкращих ознак. 3 урахуванням світових поглядів дана кониепиія повинна трунтуватися на генетичних законах успадкування, домінантного або гомозиготно-

го стану генів якісних і кількісних селекиійних ознак. Використання у наукових дослідженнях сучасних методичних підходів щзодо встановлення селекційно-генних комплексів продуктивних ознак тварин ставить під сумнів існування теорії препотентності.
\end{abstract}

Ключові слова: препотентність, домінантність, гомозиготність, гетерозиготність, плідник, ген, потомство, продуктивність.

Постановка проблеми. Збільшення виробництва свинини тісно пов'язане з якісним покращанням тварин на основі використання науково обгрунтованих методів селекції. Важлива роль генетичного впливу на результативність чистопородного поєднання та міжпородного схрещування належить плідникам, які повинні забезпечити надійний ефект гетерозису та високу якість продукції.

Особливого значення набуває й оцінка їх генетичного потенціалу та здатність стійко передавати цінні ознаки потомству. Так, за індивідуального батьківського добору потомство розподіляється на 10-12 \% середньої племінної цінності та по 44-45 \% гіршої й кращої якості, ніж їх батьки [1]. Вплив же батьків і матерів кнурів на якість потомства $€$ незначний при коефіцієнтах регресії у межах 0,1-0,2 [7].

Здатність тварин передавати потомству свої характерні особливості та продуктивні якості (навіть при поєднанні з особинами, які відрізняються між собою) у вітчизняній науковій літературі називається препотентністю.

Вивчення цього явища, у більшості досліджень спрямоване на удосконалення методів оцінки стосовно передачі певних задатків потомству, ії об'єктивності й точності, а також пошуку реалізації даної ознаки тварин у практичній селекційній роботі.
У зв'язку з цим аналітичний аналіз значимості препотентності кнурів і свиноматок, із генетикозоотехнічної точки зору, є актуальним і потребує додаткових досліджень. Першочергового значення при цьому слід надавати досягненням генетики i молекулярної біології- основи поглиблених досліджень закономірностей і розшифрування механізму руху генетичної інформації як на індивідуальному батьківському рівні, так і реалізації їх геному в наступних поколіннях [9].

Аналіз основних досліджень і публікацій, у яких започатковано розв'язання проблеми. Перехід до великомасштабної селекції у свинарстві потребує організації чіткої системи всебічної оцінки кнурів-плідників за їх фертильністю і племінними якостями [13], що сприятиме підвищенню у нащадків частоти генів, які контролюють формування високої продуктивності та відтворної здатності, пристосованості до умов експлуатації, а також запобігання поширення генетичних морфологічних дефектів та захворювань.

Процес удосконалення породи показує, що головна увага в практичній селекційній роботі завжди спрямована як на виявлення (й навіть на цілеспрямоване виведення) так і максимальне заводське використання тварин, яким властива підвищена здатність передавати потомству свої цінні якості. Як зазначав П. Н. Кулешов, окремі тварини мають здатність особливо стійко передавати потомству свої певні риси, тобто препотентність [12].

Ще $з$ середини XIX століття скотозаводчики значну увагу приділяли «підсиленій здатності окремих особин до передачі своїх властивостей спадково». Заттегестом Г. була запропонована так звана теорія «індивідуальної потенції», суть якої зводилася до того, що «новоутворення природи супроводжуються підсиленою спадковою передачею, що значна частина потомства тварин, які виділяються за яким-небудь новоутворенням, утримує цю здатність дуже стійко... і достатньо знайти плідника, що відрізняється за індивідуальною потенцією, якого б походження він не був, як подальший успіх у племінній роботі буде забезпечений» [8]. 
Із часом вислів «потенція» - (з англ. «potency»сила, могутність) трансформувався в термін «препотенція» - від латинського «рrepotece» - переважаючий, домінуючий, більш могутній.

У сільськогосподарському енциклопедичному словнику дається визначення препотентності як здатність племінних тварин (плідників і маток) стійко передавати свої якості потомству, навіть при поєднанні з тваринами, які значно відрізняються за оцінюваною ознакою й здатні в потомстві створювати відповідну однорідність. За препотентністю найчастіше оцінюють плідника, враховуючи його можливість передавати свої якості більшій кількості потомків [18].

Чимало уваги даній концепції надавали науковці минулого століття: П. Н. Кулешов (1947), Н. А. Кравченко (1957), М. М. Щепкін (1960), С. А. Рузский (1961, 1963), Н. А. Кравченко, Д. Т. Віннічук (1965), Л. К. Ернст, А. П. Солдатов (1965), Ф. Ф. Ейснер $(1970,1981)$, Е. А. Богданов (1977). Саме вони робили спроби теоретично обгрунтувати феномен препотентності й знайти математичну модель ¥ї оцінки. Так, П. Н. Кулешов, який різко критикував зеттегастівську теорію індивідуальної потенції, не лише не відкидав, а й повсякчас наголошував на значенні для селекції того факту, що окремі тварини мають здатність особливо стійко передавати потомству певні риси [12].

Видатні за своєю продуктивністю тварини, як стверджував Е.Ф. Ліскун, не тільки самі виділяються високими якостями, але й передають ці якості своєму потомству [15]. Зокрема М. М. Щепкін відмічав, що такого роду тварини виділяються не лише «індивідуальними якостями, а й видатними якостями своїх нащадків» [22], Е. А. Богданов розрізняв три ступеня (поганий, середній і хороший) у силі спадкової передачі видатними тваринами своїх якостей потомству [4]. Дане явище М. А. Кравченко пояснює так: «Препотенція, як якість племінних тварин більш стійко передавати потомкам свої ознаки, обумовлюється: більш стійкою спадковістю, яка створюється зазвичай гомогенним підбором, що проводиться тривалий час, приблизно в однакових умовах, в одному напрямку і підкріплюється родинним спарюванням; добрим станом здоров'я і пристосовуваністю до умов, відповідним підбором самок для поєднання 3 таким плідником» [11].

Добре відомо, як видатні плідники суттєво впливають на формування породи в цілому. Прикладом можуть слугувати: бик Адем 197 - у процесі формування голландської чорно-рябої породи [6], жеребець Барс 1 - у створенні орловської ри- систої породи коней [5], кнур Асканій 46 - української степової білої породи свиней [10].

На думку С. А. Рузского, виявлення препотентності плідників, головного, що визначає їх племінну цінність, повинно становити основне завдання випробування плідників по потомству. Препотентність повинна визначатися ступенем материнської спадковості [19] або здатністю вдало поєднувати й доповнювати материнську спадковість без значного іiі витіснення [20]. Це вказує на необхідність корегування плідника на вплив генетичного тренду в залежності від селекційної цінності материнської частини стада.

Найбільш вдале визначення терміна «препотенція» надав А. П. Лисицін: «Препотенція - це обумовлена домінуванням i гомозиготністю здатність тварин (як самців, так і самок) стійко передавати свої ознаки й якості потомству (сила спадкової передачі), яка фенотипово проявляється в переважаючому впливі одного з батьків на потомство (воно більш однорідне, має меншу різноякісність)» [14].

Інтерес науковців до даної проблеми в останні роки не спадає. Так, у різних галузях тваринництва проведено дослідження: у скотарстві (Е. Насамбаєв, 2006; Д. А. Попов, 2007; А. І. Шендаков, С. І. Лоскутов, 2010); у свинарстві (В. С. Мазур, А. А. Явтушенко, 2007; А. М. Івін, 2009; А. Ю. Бельтюкова, 2010); у конярстві (Н. Ю. Козлов, 2004; А. В. Гороховська, 2010); вівчарстві (Т. К. Бексеітов, 2003); птахівництві (А. Б. Мальцев, А. Д. Димков, 2010).

Для кількісного вимірювання препотентності плідників науковцями пропонуються різні методи, засновані на порівнянні дочок батька $з$ матерями, на ступені однорідності його потомства, на численності дочок із тією чи іншою вищою якістю, ніж у матерів, ровесниць та середніх показників продуктивності по стаду.

Для оцінки стійкості впливу плідників на потомків у процесі передачі генетичної інформації запропоновано чимало математичних формул та індексів. Однак найпоширенішим методом визначення $\epsilon$ кореляційний аналіз, який враховує спадковий вплив матерів і сприяє запобіганню простого арифметичного співставлення ознак у потомства 3 вираженням їх у матерів, що іноді відрізняються між собою через вплив відбору та паратипових факторів. Гіпотеза даного методу потомство препотентного плідника за селекційними ознаками більш схоже на свого батька. При цьому зменшується індивідуальна подібність потомків із матерями, тобто, більш препотентні плідники мають менші показники мінли- 
вості ознак у потомків $[4,16]$.

Мета дослідження - провести аналіз різних поглядів стосовно теорії препотентності у тваринництві.

У виконаній науковій роботі ставилося завдання: при оцінці кнурів-плідників дослідити з генетичних позицій і дати об'єктивну характеристику існування такого явища як препотентність.

Матеріал і методи досліджень. Матеріалом для теоретичних і методичних узагальнень стали історичні та сучасні зоотехнічно-генетичні уявлення теорії препотентності та їі використання у селекції сільськогосподарських тварин. Основний метод досліджень - аналітико-синтетичний.

Результати досліджень. Аналіз наукових робіт засвідчив, що минулими й сучасними вітчизняними дослідниками вивченню препотентності тварин надається значна увага, тоді як аналіз зарубіжних інформативних джерел не підтвердив використання даного терміна в селекційному процесі. Натомість в обігу зустрічається термін «домінантність», відповідно до менделівських законів успадкування якісних і кількісних ознак. Лише в словнику англійської мови Collins подано, що препотентність - це стан або становище домінування гомозиготності [21].

Саме «...домінантність і гомозиготність...» визначають спадковість кількісних продуктивних ознак від батьків потомству. Як відомо, кількісні селекційні ознаки відносяться до категорії складних і формуються за рахунок сумарної взаємодії полімерів спряжених полігенів, що породжує відповідну кількість генотипів і визначає їх частоту в популяції та рівень мінливості. До того ж чим більше генів детермінують ту чи іншу ознаку, тим вища ступінь його виявлення залежить від комбінації різних варіантів цих генів. У даному випадку пріоритет віддається не стільки наявності різних генних варіантів (спадковість батьків), скільки тому, в яких комбінаціях вони проявляються в генотипі потомства [17].

Через це вірогідне успадкування селекційної ознаки потомством у значній мірі залежить від ступеня гомозиготності кнура за комплексом бажаних генів, оскільки знижується імовірність розщеплення даних ознак у наступних генераціях. Саме це і $€$ основним постулатом визначення «сили впливу» на потомство - препотентність.

Проведені наукові дослідження не спростовують існування препотентних тварин - гомозиготних за кількісними ознаками, але таких плідників практично досить важко визначити.

Оскільки кількісні ознаки визначаються значною кількістю полігенів (майже повністю геноти- пом), то одержати гомозиготних тварин за всіма генами практично неможливо. В такому разі стандартність кількісних ознак дещо умовна, чи коливається у відповідних, хоча й невеликих межах, чим більша ступінь гомозиготності тварин, тим менші межі коливань. До того ж вони можуть бути характерними для кожної породи окремо, звичайно, за однакових умов їх існування [2].

Повна гомозиготність за всіма генами може бути лише в теоретичних розрахунках, однак у практиці, напевно, вона ніколи не зустрічається. Розщеплення генів у гаметах в одного 3 батьків, який не $є$ гомозиготним за всіма генами, призведе до того, що потомство одержить різні гени від одного i того ж батька. За даною парою алелів деякі нащадки отримують від батька один і той же ген, але, оскільки в процесі беруть участь багато пар алелів, то вірогідність одержати двома потомками однаковий набір генів від батька дуже низький. Так як інбридинг сприяє підвищенню гомозиготності за багатьма парами генів, нащадки інбредних батьків часто одержують ті ж гени, що й нащадки не інбредних батьків. Це означає, що потомство буде більш схоже за ознаками на одного з батьків, від якого вони отримали домінантний ген, а тому схожість між ними буде більшою. Тобто, інбредні батьки більш препотентні, ніж не інбредні, насамперед, за ознаками, що обумовлені домінантними генами [13].

У чистопородному стаді тварини мають більшість генів у гомозиготному й таутозиготному стані. Тому кількісні ознаки знаходяться в мінімальних межах коливань як завгодно довго, що випливає із популяційних законів ГардіВайнберга, тобто залишаються стандартними i стабільними в ряду поколінь. За систематичного відбору на стандартність кількісних ознак, межі коливань їх показників постійно зменшується, досягаючи найменшої величини, як це спостерігається у чистих лініях. I це передається з покоління в покоління без змін, а тому місця «пре потенції» й у випадку експресивності кількісних ознак не має [3].

Для селекційного поліпшення існуючих та створення нових високопродуктивних генотипів суттєве значення має пошук специфічно нової спадкової інформації, що можлива лише за поєднання гомозиготних особин, які належать до різних ліній чи типів. Тому головне завдання: підтримання гомозиготності стада й не допускати поширення небажаних мутацій, що призводять до гетерозиготності.

В практичних умовах, як стверджує О. Г. Близнюченко [3], вираженість домінантної ознаки 
однакова, як у випадку гомозиготного стану алелів, так і гетерозиготного. «До того ж, ніякої «сили передачі», «індивідуальної потенції», «підсиленої здатності» не існує, тому що реалізація вказаної ознаки не залежить ні від статі тварини, ні від віку чи інших яких-небудь його особливостей. Тому термін «препотенція» ніяк не відповідає законам успадкування, а звідси, не може бути реанімованим i, тим більше, в науково-дослідних роботах, бо це є поверненням до некомпетентності минулого».

Наша країна наразі рухається до світових цивілізованих стандартів, насамперед у свинарстві, тож необхідно коректно поступати стосовно даної концепції. Чи не було б доцільним замість терміна «препотентність» використовувати генетичні тер-

\section{БІБЛІОГРАФІЯ}

1. Бегучев А. П. Оценка производителей по качеству потомства / А. П. Бегучев, Г. П. Легошин. М. : Колос, 1973. - С. 56-65.

2. Близнюченко О. Г. Генетичні основи розведення свиней. - К. : Урожай, 1989. - 152 с.

3. Близнюченко О. Г. Препотентность - архаизм в современной науке.// Свинарство [міжвід. темат. наук. збірник]. - Полтава, 2009. - № 57. C. 33-41.

4. Богданов E. A. Изучение разведения сельскохозяйственніх животных / Богданов Е. А. - М. : Избран. труды, 1977. - 440 с.

5. Вumm В. О. Из истории русского коневодства / Витт В. О. - М., 1952. - 362 с.

6. Гринь М. П. Возможность использования препотентности быков в селекции стад / М. П. Гринь, А. А. Алешин, В. К. Казакевич // Использование генетических параметров в селекции сельскохозяйственных животных: тезисы докл. науч. конф. - Жодино, 1974. - С. 29-31.

7. Эйснер $\Phi$. Предлагаем новый метод оценки семейств / Ф. Эйснер, Ю. Белогуров // Молочное и мясное скотоводство. - 1970. - № 8. - С. 37-38.

8. Зеттегаст $\Gamma$. Учение о скотоводском искусстве / Г. Зеттегаст. - 1880. - С. 20.

9. Зубець М. В. Генетика, технология в скотоводстве / Зубець М. В., Буркат В. П., Мельник Ю. Ф.К. : БМТ, 1997. - 722 c.

10. Иванов М. Ф. Новая порода свиней - украинская степная белая, выведенная в Аскании-Нова, и методы ее образования / М.Ф.Иванов // Полное собрание сочинений. - М. : Колос, 1969. - Т. 5.C. 182-195.

11. Кравченко Н. А., Виничук Д. Т. Препотентность и методы ее измерения / Н. А. Кравченко, Д. Т. Виничук // Сб.: Разведение и содержание міни «домінантність» або «гомозиготність», тим більше, що сучасні наукові дослідження беззаперечно підтвердили на рівні ДНК теорію домінантності гомозиготних продуктивних ознак.

Висновки. Таким чином, визначення елітних плідників, здатних стійко передавати потомству високі продуктивні якості, повинне грунтуватися на генетичних законах успадкування, 3 урахуванням стану домінантності та гомозиготності селекційних ознак генотипу. Існування ж теорії препотентності всебічно залежить від умілого використання у наукових дослідженнях сучасних методичних підходів щодо встановлення рівня домінантності чи домінантної гомозиготності генних комплексів економіко-вагових продуктивних ознак тварин.

сельскохозяйственных животных. - Вып. 1. - К., 1965. - С. 61-76.

12. Кулешов П. Н. Теоретические работы по животноводству / Кулешов П. Н. - М. : Сельхозгиз, 1947. - $86 \mathrm{c}$.

13. Лесли Д. Ф. Генетические основы селекции сельскохозяйственных животных / Лесли Д. Ф. М. : Колос, 1982. - 391 с.

14. Лисицын А. П. Разведение сельскохозяйственных животных / Лисицын А. П.- М. : Агропромиздат, 1987. - 231 с.

15. Лискун E. Ф. Экстерьер сельскохозяйственных животных / Лискун И. Ф. - М. : Сельхозгиз, 1933. - $123 \mathrm{c.}$

16. Наумочкина $A$. B. Препотентность инбредных быков черно-пестрой породы // Животноводство, 1974. - №1. - С. 19.

17. Оно $C$. Генетические механизмы прогрессивной эволюции / Оно С. - М. : Мир, 1973. - 227 с.

18. Сельскохозяйственный энциклопедический словарь [ред. В. К. Месяц]. - М. : Сов. энцикл., 1989. - 656 с.

19. Рузский C. А. Оценка быков по разному числу дочерей, и значение возраста отца / С. А. Рузский // Животноводство. - №11, 1961.

20. Рузский C. A. Препотентность и некоторые проблемы межлинейного и индивидуального подбора в молочном скотоводстве / С. А. Рузский // Труды ВСХИЗО. - М. : Балашиха, 1963. C. 14-23.

21. Словарь английского языка Collins. 10-е издание, 2009, Уильям Коллинз и сыновья. - 1979, 1986, Harper Collins.

22. Щепкин М. М. Избранные сочинения / Щепкин М. М. - М. : Сельхозгиз, 1960. - С. 45-48. 